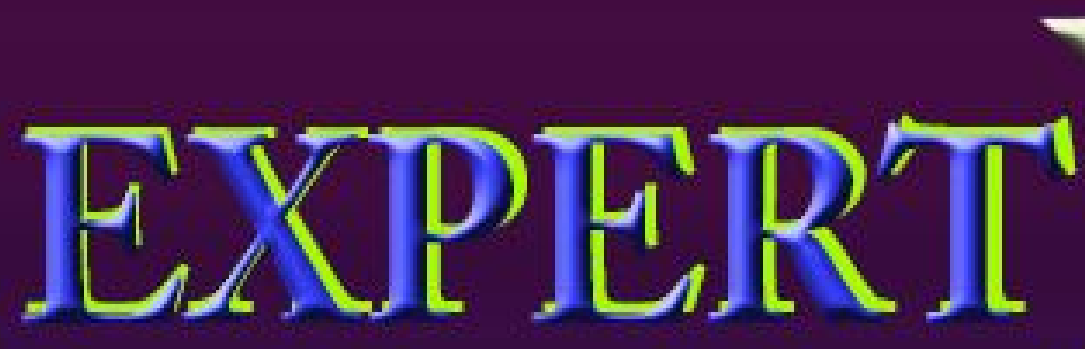

Jurnal Sistem Informasi 


\title{
METODE BACKWARD CHAINING UNTUK DIAGNOSA PENYEBAB STROKE PADA PASIEN PENDERITA
}

\author{
Rosmala Dwi \\ Program Studi Teknik Informatika Akademi Manajemen Informatika dan Komputer Mitra Lampung \\ Jln. Z.A. Pagar Alam No.7 Labuhan Ratu Bandar Lampung 35142 \\ Telp. (0721) 701418 Web. www.umitra.ac.id \\ rosmaladarma@umitra.ac.id
}

\begin{abstract}
ABSTRAK
Backward chaining merupakan metode yang digunakan di inference engiene untuk mendiagnosa 9 penyakit yang berpotensi menjadi penyebab stroke dengan melengkapi rule-rule yang akan digunakan didalam pembuatan pohon keputusan. Pohon keputusan ini akan ditelusuri dengan tehnik breadth-first search dimana node pada gejala penyakit yang ditunjukan oleh penderita akan dihubungkan dengan ars (busur) dengan menelusuri seluruh node yang ada sehingga didapatkan kesimpulan yang diinginkan. Data yang digunakan untuk membangun basis pengetahuan adalah data yang dikumpulkan dengan melakuan observasi langsung diklinik rehabilitasi pemulihan para penderita stroke, melakukan wawancara dengan beberapa orang dokter penyakit dalam dan penyakit saraf. Selain itu juga penulis menyiapkan angket yang diberikan kepada para penderita stroke untuk dapat mereka isi. Dengan penggunaan metode ini diharapkan dapat membatu dalam melakukan analisa untuk mendiagnosa yang berupa informasi penyakit penyebab penyakit stroke sehingga dapat segera dilakukan pencegahan dan pengobatannya.
\end{abstract}

Kata kunci : Backward Chaining, breadth-first search, Stroke, Penyakit Penyebab Stroke

\section{PENDAHULUAN \\ 1.1 Latar Belakang}

Backward chaining merupakan salah satu metode yang digunakan di inference engiene untuk menggunakan informasi yang diberikan untuk menemukan objek yang sesuai.

Stroke merupakan salah satu penyakit yang cukup berbahaya di Indonesia. Penyakit yang diawali dengan tanda seperti mati rasa yang berada di wajah, kaki, lengan, ataupun di sisi salah satu tubuh, disertai dengan adanya kebingungan dan sulit untuk bicara. Berbicara tentang penyakit yang melumpuhkan bahkan mematikan penderitaanya ini sering diketahui ketika telah parah. Bila didalam riwayat keluarga ditemui ada yang menderita stroke maka akan lebih baik untuk lebih diwaspadai. Tapi bukan berarti kita akan menderita stroke juga hanya berpeluang lebih besar untuk menderita stroke. Usia, ras, etnik, atau jenis kelamin merupaka faktor pemicu yang tida dapat di rubah. Namun ada faktor pemicu yang bisa di rubah yaitu dengan adanya penyakit lain seperti jantung, hipertensi, ginjal, diabetes, obesitas.

Dengan mengetahui penyakit yang menjadi pemicu timbulnya stroke akan membantu menguranngi resiko terburuk dari stroke ini. Pemanfaatan metode backward chaining dalam mendiagnosa penyakit penyebab stroke pada pasien diharapkan dapat membantu dalam mendiagnosa penyakit yang menjadi penyebab utama pasien menderita stroke. Sehingga penanggulangan dapat dilakukan dari awal untuk mengurangi resiko terburuk dari stroke yang diderita.

\subsection{Permasalahan Penelitian \\ 1.2.1. Identifikasi Masalah}

Dari latar belakang permasalahan diatas penulis menemukan ada beberapa permasalahan, yaitu :

a. Kurangnya pengetahuan dan kemampuan masyarakat dalam mengetahui penyakit penyebab stroke sehingga sering terjadi keterlambatan penanganan terhadap stroke ini.

b. Dalam melakukan diagnosa terhadap gejala dini yang dapat menimpa seseorang masyarakat sangat bergantung dengan tenaga medis sehingga sering terjadi keterlambatan dalam memberikan pertolongan terhadap pasien penderita stroke.

\subsection{Rumusan dan Batasan Masalah \\ 1.3.1. Rumusan Masalah}

Beradasarkan uraian permasalahan diatas maka permasalahan yang penulis rumuskan adalah "Bagaimana memanfaatkan metode Backward Chaining untuk membantu dalam mmendiagnosa penyakit penyebab stroke yang diderita oleh pasien penderitanya?"

\subsubsection{Batasan Masalah}

Luasnya permasalahan di ruang lingkup penyakit stroke, maka pada penelitian ini penulis membatasi hanya diseputar gejala yang dinampakkan oleh penderita untuk memastikan penyakit yang menyebabkan stroke pada pasien penderita. Sedangkan tehnik penelurusuran yang digunakan adalah tehnik breadth-first search. 


\subsection{Tujuan Penelitian} adalah :

Tujuan dari penelitian yang dilakukan ini

a. Berdasarkan gejala yang dimiliki dari pasien penderita stroke akan dilakukan penalaran kebelakang untuk mendiagnosa penyakit yang menjadi penyebab stroke pada pasien.

b. Memanfaatkan metode backward chaining dalam menganalisa gejala yang ditujukan oleh pasien untuk mendiagnosa penyakit penyebab terjadinya stroke.

\section{TINJAUAN PUSTAKA DAN LANDASAN TEORI}

\subsection{Tinjauan Pustaka}

Dalam melakukan penelitian diambil dari beberapa referensi pada penelitian sebelumnya, yaitu :

a. Pemanfaatan Certainty Factor Dalam Menentukan Jenis Penyakit Penyebab Stroke (Rosmala, 2017)

b. An Expert System of Measurement of Individual Knowledge for Teeth Treatment (Debora, 2015)

c. An Assessment of The Efficiency of and Child Preference for Forward and Backward Chaining (Nurhakim, 2017)

d. Component Evaluation of a Computer Based Format for Teaching Discrete Trial and Backward Chaining.(Imron, 2016)

\subsection{Landasan Teori}

\subsubsection{Stroke}

Stroke atau dengan istilah gangguan peredaran darah otak (GPDO) adalah sindrom yang disebabkan oleh gangguan aliran darah di sebagian otak sehingga menimbulkan gangguan fungsional otak yang berupa defisit neurologik atau kelumpuhan pada syaraf (Rosmala, 2017)

Ada dua jenis faktor resiko stroke, (Rosmala, 2017) yaitu :

a. Faktor risiko yang tidak dapat diubah, yaitu umur, jenis kelamin, riwayat keluarga, ras

b. Faktor risiko yang dapat diubah, yaitu hiper tensi, merokok, diabetes mellitus, penyakit kardiovaskular, kolesterol tinggi, peningkatan hematokrit meningkatkan risiko infark serebral, kontrasepsi oral, obesitas,konsumsi alkohol, penyalah gunaan obat (khususnya kokain)

\subsubsection{Penyebab Penyakit Stroke}

Beberapa penyebab penyakit stroke memang harus diperhatikan agar bisa lebih waspadai untuk dapat menjaga tubuh agar terhindar dari beberapa penyakit yang memang berpeluang menyebabkan stroke. Beberapa penyakit tersebut adalah (Rosmala, 2017) :

\section{a. Hipertensi}

Hipertensi adalah gangguan di pembuluh darah yang mengakibatkan terhambatnya suplai oksigen dan nutrisi sampai ke jaringan tubuh yang membutuhkan. Kriteria objektif hipertensi adalah sakit kepala, pusing, sering migran, pendarahan dari hidung, wajah kemerahan, mudah lelah, penglihatan kabur (Rosmala, 2017)

\section{b. Penyakit Jantung}

Seseorang yang menderita penyakit jantung dapat dikenali lewat gejala-gejala yang ada pada pasien tersebut, yaitu sering kelelahan, mual berlebihan, sering berkeringat, merasa cemas, tegang, nyeri pada bagian tubuh, denyut jantung tidak teratur, pembengkakan pada kaki dan perut (Rosmala, 2017).

\section{c. Diabetes millitus}

Diabetes millitus adalah sindrom yang diakibatkan kekurangan atau hilangnya hormon insulin. Seseorang yang menderita diabetes militus dapat dikenali lewat gejala-gejala yang ada pada pasien tersebut, yaitu cepat haus, sering kencing, penurunan berat badan yang drastic (Rosmala, 2017)

\section{d. Hiperklosterolemia/displemia}

Hiperkolesterolemialdisplemia merupakan peninggian kadar kolesterol dalam darah. Seseorang yang menderita Hiperklosterolemial displemia dapat dikenali lewat gejala-gejala yang ada pada pasien tersebut, yaitu berat badan berlebihan, sakit kepala, mengalami aterosklosis secara spontan, kurang aktivitas.

\section{e. Kolestrol Darah}

Kolesterol adalah lemak berwarna kekuningan dan berupa seperti lilin yang diproduksi oleh tubuh manusia terutama di dalam hati. Seseorang yang menderita Hiperklostero lemia/displemia dapat dikenali lewat gejala yang mudah lelah, mudah mengantuk, kaki bengkak, rasa sakit atau pegal ditengkuk kepala bagian belakang, pegal sampai pundak (Rosmala, 2017) .

\section{f. Obesitas}

Obesitas atau kegemukan mempunyai pengertian yang berbeda-beda bagi setiap orang. Terkadang kita sering dibuat bingung dengan pengertian obesitas dan overweight, padahal kedua istilah tersebut mempunyai pengertian yang berbeda. Obesitas adalah suatu kondisi kelebihan berat tubuh akibat tertimbunnya lemak, untuk pria dan wanita masing- masing melebihi $20 \%$ dan $25 \%$ dari berat tubuh dan dapat membahayakan kesehatan. Sementara overweight (kelebihan berat badan, kegemukan) adalah keadaan dimana BB seseorang melebihi BB normal. Seseorang yang menderita obesitas dapat dikenali lewat gejalagejala yang ada pada pasien tersebut, yaitu berat 
badan meningkat tidak jelas, selulit, sakit lutut, varices, sulit bernafas (Rosmala, 2017) .

\section{g. Asam Urat}

Asam urat adalah asam yang berbentuk kristalkristal yang merupakan hasil akhir dari metabolisme purin (bentuk turunan nukleoprotein), yaitu salah satu komponen asam nukleat yang terdapat pada inti sel-sel tubuh. Secara alamiah, purin terdapat dalam tubuh kita dan dijumpai pada semua makanan dari sel hidup, yakni makanan dari tanaman (sayur, buah, kacang-kacangan) atau pun hewan (daging, jeroan, ikan sarden). Seseorang yang menderita asam urat dapat dikenali lewat gejala yaitu sendi terasa nyeri, sendi terasa meradang, sendi terasa membengkak, sendi terasa panas, sendi kaku, kaki keseleo, benjolan disekitar sendi yang meradang (Rosmala, 2017).

\section{h. Ginjal}

Seseorang yang menderita gagal ginjal kronis merupakan gangguan fungsi renal yang progresif dan irreversibel dimana kemampuan tubuh gagal untuk mempertahankan metabolisme dan keseimbangan cairan dan elektrolit yang menyebabkan uremia. Penyakit gagal ginjal kronik dapat dikenali lewat gejala, yaitu tidak keluar urin, nafsu makan menurun, mual, pucat, kencing sedikit, kram, sering merasa anemia (Rosmala, 2017)

\section{i. Usia}

Umur merupakan faktor resiko stroke, dimana semakin bertambahnya usia seseorang maka resiko untuk terserang stroke semakin tinggi

\subsubsection{Teori Metode Inferensi}

Metode inferensi adalah sebuah mekanisme berfikir dengan pola penalaran yang digunakan oleh sistem untuk mencapai suatu kesimpulan. Metode ini akan menganalisa masalah tertentu dan selanjutnya mencari kesimpulan yang terbaik. Penalaran dimulai dengan mencocokkan kaidahkaidah dalam basis pengetahuan dengan fakta yang ada (Debora, 2015) .

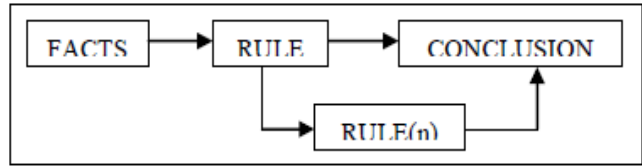

Gambar 1. Proses didalam mesin Inferensi (Debora, 2015)

Ada dua metode inferensi dengan rule didalam sistem pakar yaitu (Imron, 2016) :

1) Forward chaining

Forward chaining adalah aturan-aturan yang diuji satu demi satu dalam urutan tertentu (data driven). Jika klausa premis sesuai dengan situasi (bernilai TRUE), maka proses akan meng-assert solusi. Bila inference engine tidak dapat dapat menentukan objek maka akan meminta informasi lain. Aturan (rule) dimana menentukan objek, membentuk path (lintasan) yang mengarah ke objek. Oleh karen itu, hanya satu cara untuk mencapai satu objek adalah memenuhi semua aturan (Imron, 2016) .

\section{2) Backward chaining}

Backward Chaining merupak penalaran yang dimulai dari kesimpulan dan akan dibuktikan kebenarannya (goal driven) (Imron, 2016)

\subsubsection{Metode Backward Chaining}

Metode ini akan melakukan pendekatan goaldriven, yang diawal dengan apa yang terjadi dan dilanjutkan dengan mencari bukti-bukti yang mendukung hipotesa yang kita punya (Nurhakim, 2017) .

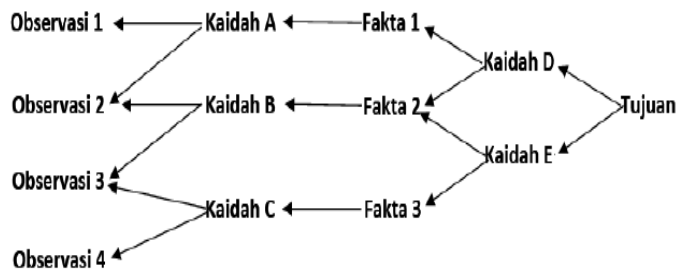

Gambar 3. Diagram Backward chaining (Nurhakim, 2017)

\subsubsection{Tehnik Breadh-first search}

Merupakan tehnik penelusuran data yang dilakukan pada semua node dalam satu level yang sama sebelum dilanjutkan pada level dibawahnya. Keuntungan menggunakan teknik adalah semua node yang dicek akan dilakukan secara menyeluruh pada setiap tingkatan node. Kekurangan dari tehnik ini adalah dari segi waktu yang cukup lama untuk mendapatkan solusi apabila solusi yang dibutuhkan berada di posisi node terakhir (Nurhakim, 2017).

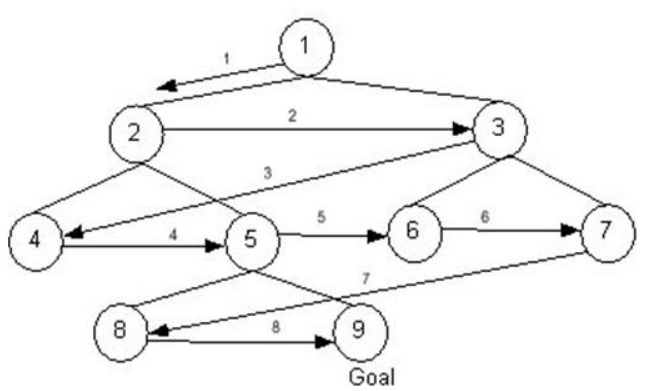

Gambar 4. Tehnik breadth -first search (Sarah, 2017) 


\section{METODE PENELITIAN}

Untuk mendapatkan data dalam penelitian ini ada beberapa tehnik yang penulis lakukan, yaitu :

a. Wawancara

Dengan melakukan tanya jawab dengan beberapa dokter penyakit dalam dan penyakit saraf untuk menganalisa penyakit stroke dan 9 penyakit dalam yang menjadi penyebab stroke. b. Angket

Tehnik ini dengan mengajukan pertanyaan yang di buat kedalam angket yang dapat digunakan oleh para penderita penyakit stroke dalam menjawab pertanyaan penulis untuk mendapatkan data penelitian.

c. Observasi

Dengan melakukan pengamatan langsung di klinik rehabilitasi pemulihan para penderita penyakit stroke.

\subsection{Basis Pengetahuan}

Basis pengetahuan yang terbangun kumpulan fakta-fakta dan aturan yang dipakai oleh beberapa pakar yang dipresentasikan dalam bentuk $I F$ THEN. Selain itu juga, bentuk ini akan digunakan apabila diperlukan penjelasan tentang tahap-tahap pencapaian solusi.

\subsubsection{Tabel Pakar}

Tabel pakar berisikan basis pengetahuan penting dari suatu sistem pakar. Besar kecilnya kemampuan system pakar akan ditentukan oleh kapasitas dari basis pengetahuan yang dimiliki oleh sistem pakar. Sedangkan mesin pengambilan keputusan adalah aplikasi yang memandu pengguna sistem pakar dalam memanipulasi data dan memilih pengetahuan yang sesuai untuk mendapatkan pengetahuan

\section{PEMBAHASAN}

Tabel 1. Kode Penyakit

\begin{tabular}{|c|c|c|c|c|c|c|c|c|c|}
\hline \multicolumn{10}{|c|}{ Kode Penyakit } \\
\hline Kode Gejala & P1 & $\mathbf{P 2}$ & P3 & P4 & P5 & P6 & P7 & P8 & P9 \\
\hline G01 & $X$ & $\mathrm{X}$ & & $\mathrm{X}$ & & & & & \\
\hline G02 & $\mathrm{X}$ & & & & & & & & \\
\hline G03 & $\mathrm{X}$ & & & & & & & & \\
\hline G04 & $\mathrm{X}$ & & & & & & & & \\
\hline G05 & $X$ & & & & & & & & \\
\hline G06 & $X$ & $\mathrm{X}$ & & & $\mathrm{X}$ & & & & \\
\hline G07 & $\mathrm{X}$ & & & & & & & & \\
\hline G08 & & $\mathrm{X}$ & & & & & & & \\
\hline G09 & & $\mathrm{X}$ & & & & & & & \\
\hline G10 & & $\mathrm{X}$ & & & & & & & \\
\hline G11 & & $\mathrm{X}$ & & & & & & & \\
\hline G12 & & $\mathrm{X}$ & & & & & & & \\
\hline G13 & & $\mathrm{X}$ & & & & & & & \\
\hline G14 & & $\mathrm{X}$ & & & & & & & \\
\hline G15 & & & $X$ & & & & & & \\
\hline G16 & & & $\mathrm{X}$ & & & & & & \\
\hline G17 & & & $\mathrm{X}$ & & & & & & \\
\hline G18 & & & & $X$ & & $\mathrm{X}$ & & & \\
\hline G19 & & & & $X$ & & & & & \\
\hline G20 & & & & $\mathrm{X}$ & & & & & \\
\hline G21 & & & & & $\mathrm{X}$ & & & & \\
\hline G22 & & & & & $\mathrm{X}$ & & & & \\
\hline G23 & & & & & $\mathrm{X}$ & & & & \\
\hline $\mathrm{G} 24$ & & & & & $\mathrm{X}$ & & & & \\
\hline G25 & & & & & & $\mathrm{X}$ & & & \\
\hline G26 & & & & & & $\mathrm{X}$ & & & \\
\hline $\mathrm{G} 27$ & & & & & & $\mathrm{X}$ & & & \\
\hline G28 & & & & & & $\mathrm{X}$ & & & \\
\hline G29 & & & & & & & $\mathrm{X}$ & & \\
\hline G30 & & & & & & & $\mathrm{X}$ & & \\
\hline G31 & & & & & & & $\mathrm{X}$ & & \\
\hline G32 & & & & & & & $\mathrm{X}$ & & \\
\hline G33 & & & & & & & $\mathrm{X}$ & & \\
\hline G34 & & & & & & & $\mathrm{X}$ & & \\
\hline G35 & & & & & & & $\mathrm{X}$ & & \\
\hline G36 & & & & & & & & $\mathrm{X}$ & \\
\hline G37 & & & & & & & & $\mathrm{X}$ & \\
\hline G38 & & & & & & & & $\mathrm{X}$ & \\
\hline G39 & & & & & & & & & $\mathrm{X}$ \\
\hline G40 & & & & & & & & & $\mathrm{X}$ \\
\hline G41 & & & & & & & & & $\mathrm{X}$ \\
\hline
\end{tabular}


Keterangan dari penyakit

$\begin{array}{lll}\text { Kode Penyakit } & & \text { Nama Penyakit } \\ \text { P1 } & = & \text { Hipertensi } \\ \text { P2 } & = & \text { Jantung } \\ \text { P3 } & = & \text { Diabetes Militus } \\ \text { P4 } & = & \text { Hiperklosterolemia } \\ \text { P5 } & = & \text { Kolestrool Darah } \\ \text { P6 } & = & \text { Obesitas } \\ \text { P7 } & = & \text { Asam Urat } \\ \text { P8 } & = & \text { Ginjal } \\ \text { P9 } & = & \text { Usia }\end{array}$

Keterangan dari gejala

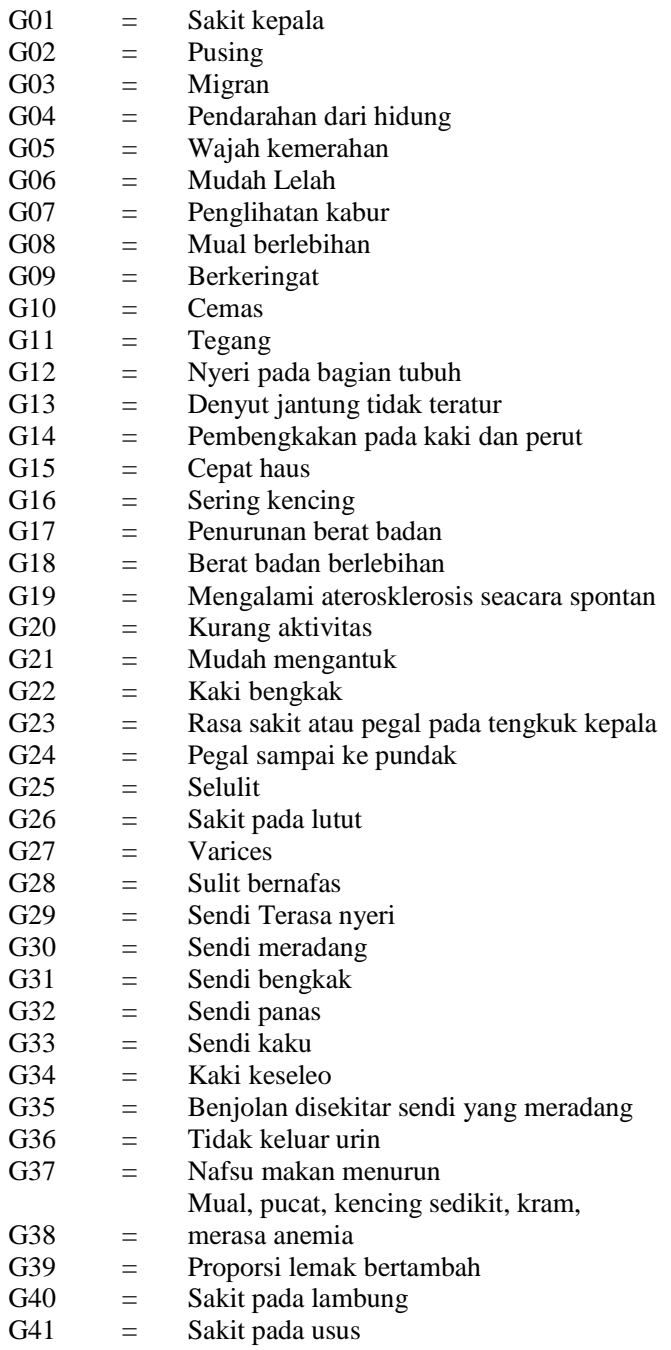

\subsubsection{Rule-rule pada Pakar}

Rule 1

Jika sakit kepala, pusing, sering migrant, pendarahan dihidung, wajah kemerahan, mudah lelah dan penglihatan kabur Maka terindikasi menderita penyakit hipertensi.

\section{Rule 2}

Jika sering kelelahan, mual berlebihan, sering berkeringat, merasa cemas, tegang, nyeri pada bagian tubuh, sakit kepala, denyut jantung tidak teratur dan pembekakan pada kaki dan perut Maka terindikasi menderita penyakit jantung.

\section{Rule 3}

Jika cepat haus, sering kencing dan penurunan berat badan Maka terindikasi menderita penyakit diabetes militus.

\section{Rule 4}

Jika berat badan berlebihan, sakit kepala, mengalami aterosklerosis secara spontan dan 
kurang aktivitas Maka terindikasi menderita penyakit.

\section{Rule 5}

Jika mudah mengantung, kaki bengkak, rasa sakit/pegal ditengkuk kepala bagian belakang dan pegal sampai ke pundak Maka terindikasi menderita penyakit kolesterol darah.

\section{Rule 6}

Jika berat badan meningkat tidak jelas, selulit, sakit lutut, varices dan sulit bernafas Maka terindikasi menderita penyakit obesitas.

\section{Rule 7}

Jika sendi terasa nyeri, sendi terasa meradang, sendi terasa membengkak, sendi terasa panas, sendi kaku, kaki keseleo dan benjolan disekitar sendi Maka terindikasi menderita penyakit asam urat.

\section{Rule 8}

Jika tidak keluar urin, nafsu makan menurun, mual, pucat, kencing sedikit, keram dan sering merasa anemia Maka terindikasi menderita penyakit ginjal.

\section{Rule 9}

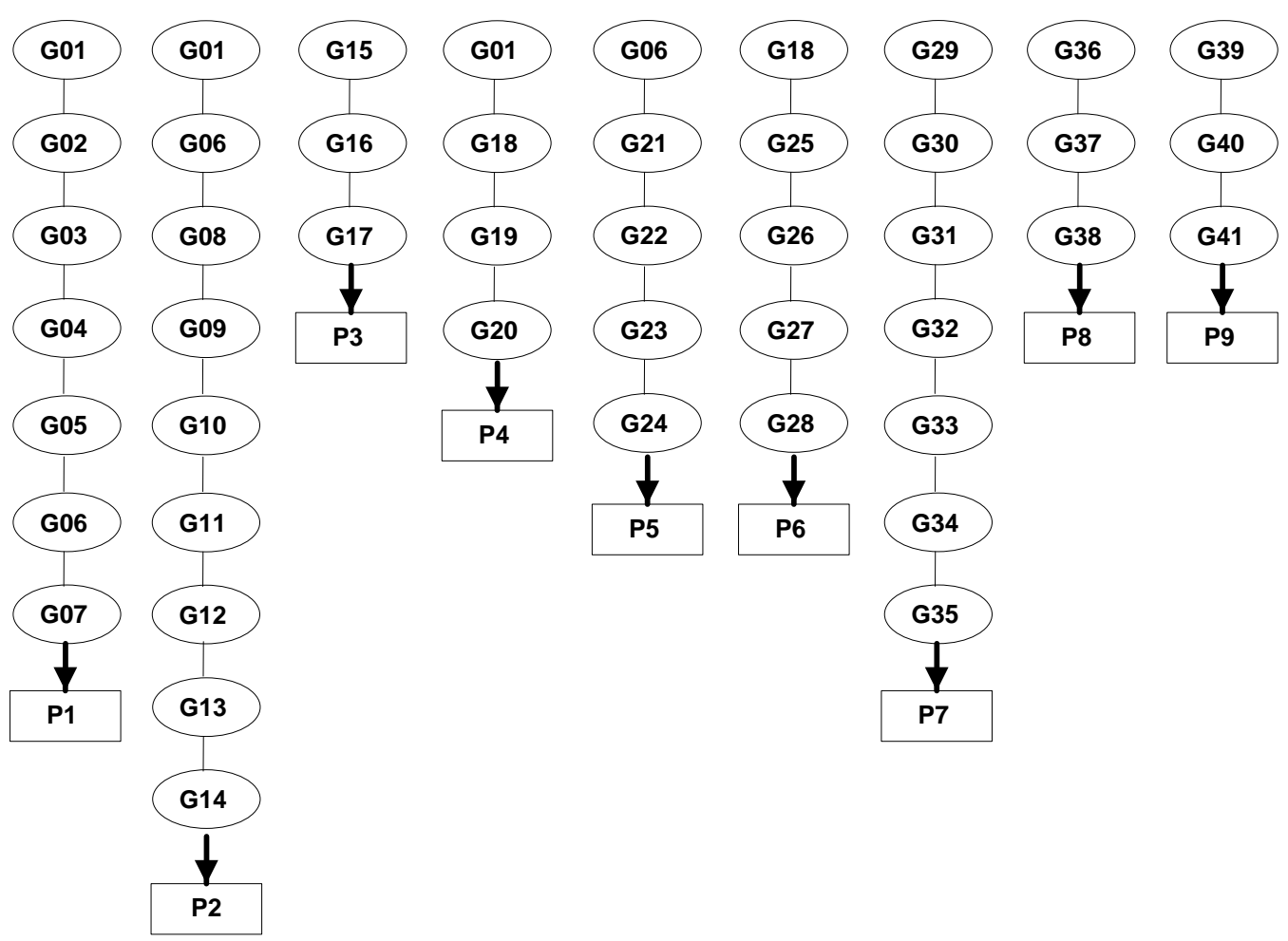

Gambar 5. Pohon keputusan penyakit penyebab stroke dan gejalanya

\section{KESIMPULAN}

Dari hasil penelitian yang telah dilakukan terhadap gejala yang ditunjukkan 9 penyakit yang berpotensi menyebabkan stroke dengan
Jika proposi lemak bertambah, sakit pada lambung dan sakit pada usus Maka terinikasi karna faktor usia.

\subsubsection{Pohon Keputusan}

Pohon merupakan penggambaran dari struktur secara hirarki. Dimana node-node yang menunjukan objek pada gejala yang ditujukkan pasien dan ars (busur) yang menunjukkan hubungan antar gejala satu dengan gejala lain untuk menyimbulkan dari penyakit yang diderita pasien sehingga dapat mengakibatkan stroke. Penelusuran pada kasus ini akan digunakan tehnik breadh-first search yang akan dimulai dari node awal dari diagram yang dilambangkan dengan G01, dari node tersebut bercabang ke node selajutnya dengan kaida ya atau tidak. Bila salah satu kaidah tidak terpenuhi maka penelusuran akan dilanjutkan pada node node selanjutnya secara berurut sampai nsebuah node yang dapat memenuhi seluruh kaidah yang telah ditetapkan terpenuhi. Node gejala penyakit akan disimbilkan dengan $\mathrm{G}$ dan node yang dimulai dengan 01. Untuk penyakit disimbulkan dengan $\mathrm{P}$ yang dimulai dengan 1 . 
a. Waktu yang digunakan dengan penelusuran breadth-first search cukup lama jika data yang akan ditelusuri mlah node yang besar dikarenakan tehnik ini akan melakukan penelusuran secara sequential sampai kaidah yang ada memenuhi persyaratan untuk dapat dipergunakan solusi yang dimaksud.

b. Data yang digunakan untuk menganalisa penyakit penyebab stroke ini dibangun berdasarkan pengetahuan yang didapat dari pakar di dibang penyakit dalam dengan menggunakan metode runut mundur (backward chaining) yaitu sebuah metode sebuah metode yang menganalisa berdasarkan hipotesa yang ada untuk kemudian mengunpulkan fakta-fakta yang dapat mendukung hipotesa tersebut.

\section{DAFTAR PUSTAKA}

[1] Rosmala Dwi. 2017. Pemanfaatan Certainty Factor Dalam Menentukan Jenis Penyakit Penyebab Stroke. Jurnal Explore. Vol. 8. No. 2. ISSN : 2087-2062
[2] Debora Valentina Silitonga, Widodo Budi harto. 2015. An Expert System of Measurement of Individual Knowledge for Teeth Treatment. International Journal of Software Engineering and Its Applications. Vol. 9. No. 4. Pages 11-18. ISSN: 17389984

[3] Imron. 2016. Sistem Pakar Analisa Kerusakan Pada Sepeda Motor Transmisi Automatic dengan Metode Backward Chaining . Jurnal Teknik Informatika STMIK Antar Bangsa. Vol. II. No.2

[4] Nurhakim, Frisma Handayana, Rinawati. 2017. Sistem Pakar Diagnosa Autisme pada Anak Berbasis Android. Jurnal Sains Komputer \& Informatika (J-SAKTI). Vol 1. No. 2. ISSN:2548-9771/EISSN: 2549-7200

[5] Sarah K. Slocum, Jeffrey H. Tiger. 2011. An Assessment of The Efficiency of and Child Preference for Forward and Backward Chaining. Applied Behavior Analysis. Vol 44. Issue 4. Pages 793-805. DOI: 10.1901/jaba.2011.44-793 
Redaksi :

Pusnt Studi Toknologi Informmai Fakultar IImu Komputer Univorgitas Bandar Lampung Gedung M Lt. 2 J1. Znirnal Pagar Alam No.89, Gedong Meneng. Rajabnsa Bandar Lampung g 772088555000

Bmail : jurnalfik@ubl,nc.fd 